\title{
Genetic variability in white-tailed deer
}

\author{
David D. Breshears, ${ }^{*}$ \\ Michael H. Smith, \\ E. Gus Cothrant and \\ Paul E. Johns
}

Savannah River Ecology Laboratory,

Drawer E. Aiken, SC 29801, U.S.A.

\begin{abstract}
Genetic variability at 36 loci was studied in white-tailed deer (Odocoileus virginianus) populations, on the Savannah River Plant (SRP) in South Carolina. Mean multilocus heterozygosity $(\bar{H})$, percentage of polymorphic loci $(P)$ and average number of alleles per locus $(A)$ for white-tailed deer were calculated and compared with values for white-tailed deer from several locations (SRP deer: $\bar{H}=9.9$ per cent, $P_{0.05}=30.6$ per cent, $A=1 \cdot 89$; white-tailed deer overall: $\bar{H}=10.4$ per cent, $P_{0.05}=32.3$ per cent, $\left.A=1.94\right)$. Frequency distributions for single locus heterozygosity values $(h)$ and the number of alleles per locus for white-tailed deer were found to be significantly different from those of mammals in general. Analysis of single-locus data based on quaternary structure and functional groups of proteins failed to demonstrate expected differences as predicted from the literature. White-tailed deer have a high level of heterozygosity, but they do not exhibit many of the life history and environmental characteristics associated with high heterozygosity in other animals.
\end{abstract}

\section{INTRODUCTION}

Genetic variability is an important characteristic of populations (Mitton and Grant, 1984) and is the basis for a number of conceptual issues in population genetics (Crow and Kimura, 1970). Understanding of genetic variability requires comparisons at the intra- (e.g., Selander et al., 1971; Tamarin and Krebs, 1973; DiMichele and Powers, 1982) and interspecific levels (Nevo, 1978). Genetic variability in white-tailed deer, Odocoileus virginianus, has been studied both temporally and spatially (Manlove et al., 1976; Ramsey et al., 1979; Chesser et al., 1982) and comparisons have been made with other closely related taxa (Baccus et al., 1983; Smith et al., 1986). These studies have not statistically compared the level of genetic variability in white-tailed deer to that of mammals or vertebrates in general.

A large number of loci and an adequate sample size are required for reliable estimates of genetic variability. Three common measures of genetic variability, multi-locus heterozygosity $(\bar{H})$, alleles

Present addresses: * Colorado State University, Department of Radiology and Radiation Biology, Fort Collins, CO 80523, U.S.A. † University of Kentucky, Department of Veterinary Sciences, 102 Animal Pathology Building, Lexington, KY 40546, U.S.A. per locus $(A)$ and percentage of polymorphic loci $(P)$ are affected differentially by a low number of individuals sampled and loci analysed. Heterozygosity estimates are especially sensitive to the number of loci analysed (Nei, 1975). Alleles per locus and percentage of polymorphic loci are most affected by number of individuals sampled, especially at low numbers. Estimates of genetic variability are expected to change with increasing samples and number of loci analysed (Nevo, 1978). Several estimates of genetic variability have been made for white-tailed deer, but most of these have involved 22 or fewer loci (Ramsey et al., 1979; Hillestad, 1984; Smith et al., 1984). Sample sizes varied considerably and ranged from 32 to over 316 for a variety of populations from the southeastern United States (Smith et al., 1984).

There were three objectives in this study. First, values of $\bar{H}, P$, and $A$ are reported for a large sample of white-tailed deer from the Savannah River Plant (SRP) analysed for variation at 36 loci. Second, these data were compared with other available data for deer from other localities, and all data for this species were combined to obtain overall estimates of genetic variability for comparison with those for mammals and vertebrates in general. Third, the data for white-tailed deer were organised into groups based on the 
quaternary structure or functional characteristics of the proteins, and hypotheses explaining levels of genetic variability of these groups were tested.

\section{MATERIALS AND METHODS}

Genetic variation in white-tailed deer was studied by means of horizontal starch gel electrophoresis. For this analysis, muscle, liver, and blood samples from 500 white-tailed deer were obtained in 1981 from hunts on the SRP near Aiken, South Carolina. Muscle samples were taken from the abdominal area, placed in vials with liver samples and put on ice; samples were stored in an ultra-cold freezer at $-60^{\circ} \mathrm{C}$. Blood samples were handled as described by Manlove et al. (1975). Techniques of electrophoresis were those described by Manlove et al. (1975) except as noted. Banding patterns were interpreted independently by at least two individuals. If the scorings were not consistent, the gel was reexamined and if necessary the samples were subjected to electrophoresis again.

Diagnostic tests for muscle samples were performed using lithium hydroxide and tris-maleate gels (Selander et al., 1971) to determine which enzymes could be stained with good resolution for this tissue. Eight proteins were chosen for further study after testing 21 stains. Fumerate hydratase ( $F h$; Harris and Hopkinson, 1976), mannosephosphate isomerase (Mpi-1; Nichols et al., 1973), and peptidase ( $P e p$ with DL-leucylglycylglycine as a stain substrate; Harris and Hopkinson, 1976) were stained on the lithium gel. Creatine kinase ( $C k$; Harris and Hopkinson, 1976), glutamate dehydrogenase (Gdh-1; Manlove et al., 1975), glucokinase ( $G k$; same stain as for hexokinase in Harris and Hopkinson, 1976), isocitrate dehydrogenase (Icd; Selander et al., 1971), and malic enzyme (Mod; Selander et al., 1971) were stained on a tris-maleate gel with $1 \mathrm{ml}$ of NADP added to the gel during cooking. Four sets of bands were observed for $C k$, but only the $C k-2$ and $C k-4$ loci had consistent bands. Two sets of bands were observed for Mod but only those of Mod-2 were present consistently. Three Pep loci and two Icd loci were resolved. All 12 presumed loci analysed from the muscle samples are reported on for the first time for the SRP herd except for Icd-1 and 2, Gdh-1 and Mod-2, which had been studied previously by Manlove et al. (1975) in a smaller sample of deer.

Liver and blood samples were studied as in Manlove et al.(1975) for the following systems: Aat-1, Aat-2, Es-2, $\alpha H b, \beta H b, L d h-2, M d h-1$,
Mdh-2, Pgm-2, Sordh, and Tf (abbreviations in table 1). Mean heterozygosity for all loci studied $(\bar{H})$ in SRP deer was calculated from $h$ values for 36 loci. The standard deviation for $\bar{H}$ was calculated from $h$ for individual loci, and confidence intervals for $\bar{H}$ are expressed \pm one standard error. The $h$ values were obtained by direct count of heterozygotes except those of $\alpha \mathrm{Hb}$; the $h$ value for this locus was calculated from allele frequencies as determined from the number of homozygous null phenotypes by use of the Hardy-Weinberg equations (Hartl, 1980). Heterozygosity values for single loci $(h)$ were less than 0.01 for the following loci based on examination of 2000 or more deer collected from 1974 through 1981 (Ramsey et al., 1979; Scribner et al., 1985): Alb, Es-1, Es-3, Es-4, Gd, Gpd-1, Gpd-2, Gpi-1, Gpi-2, Ldh-1, Pgd, Ppt-b, and Sod-1 (table 1). The value of $h$ for each locus listed above was assumed to be 0 in calculating $\vec{H}$. In addition to our observations of $I c d-1$ and $I c d-2$ for 500 individuals, 2000 additional deer had previously been studied with low frequency variants for $I c d-1$ but no variants for $I c d-2$.

Alleles were designated by percent mobility of their product relative to those of the common allele, arbitrarily designated as 100 . Alleles with products that migrated cathodally were designated by negative numbers. Loci were designated in numerical order by the position of their product beginning at the anode and going towards the cathode with the exception of hemoglobin (Huisman et al., 1968).

Sheffield (1983) studied genetic variability in white-tailed deer from Maryland. Numerous loci $(N=57)$ were analysed, but frequently for relatively few individuals ( $N=$ at least 37$)$. An overall value of $h$ for white-tailed deer from the SRP and Maryland was calculated for each locus as an unweighted mean. A locus was considered polymorphic if the secondary alleles occurred at a frequency of $\geqq 0.01$ in either area. Overall $A$ was based on total number of alleles demonstrated in any population of white-tailed deer (Manlove et al., 1975; Erickson, 1979; Manlove, 1979; Price et al., 1979; Ramsey et al., 1979; Hillestad, 1984, Smith et al., 1984; Smith et al., 1986). Because comparisons were not available between all studies, a conservative estimate of the maximum number of alleles was made based on the gel type used in the analysis and the relative position of the allelic products. Data for $A$ were divided into categories of 1,2,3 and more than 3 alleles per locus for SRP and overall white-tailed deer samples. The $h$ values also were grouped into 
Table 1 A list of 36 loci studied in white-tailed deer from the Savannah River Plant. Their abbreviations, heterozygosities (h), allele designations, tissue types and preferred gel types are given

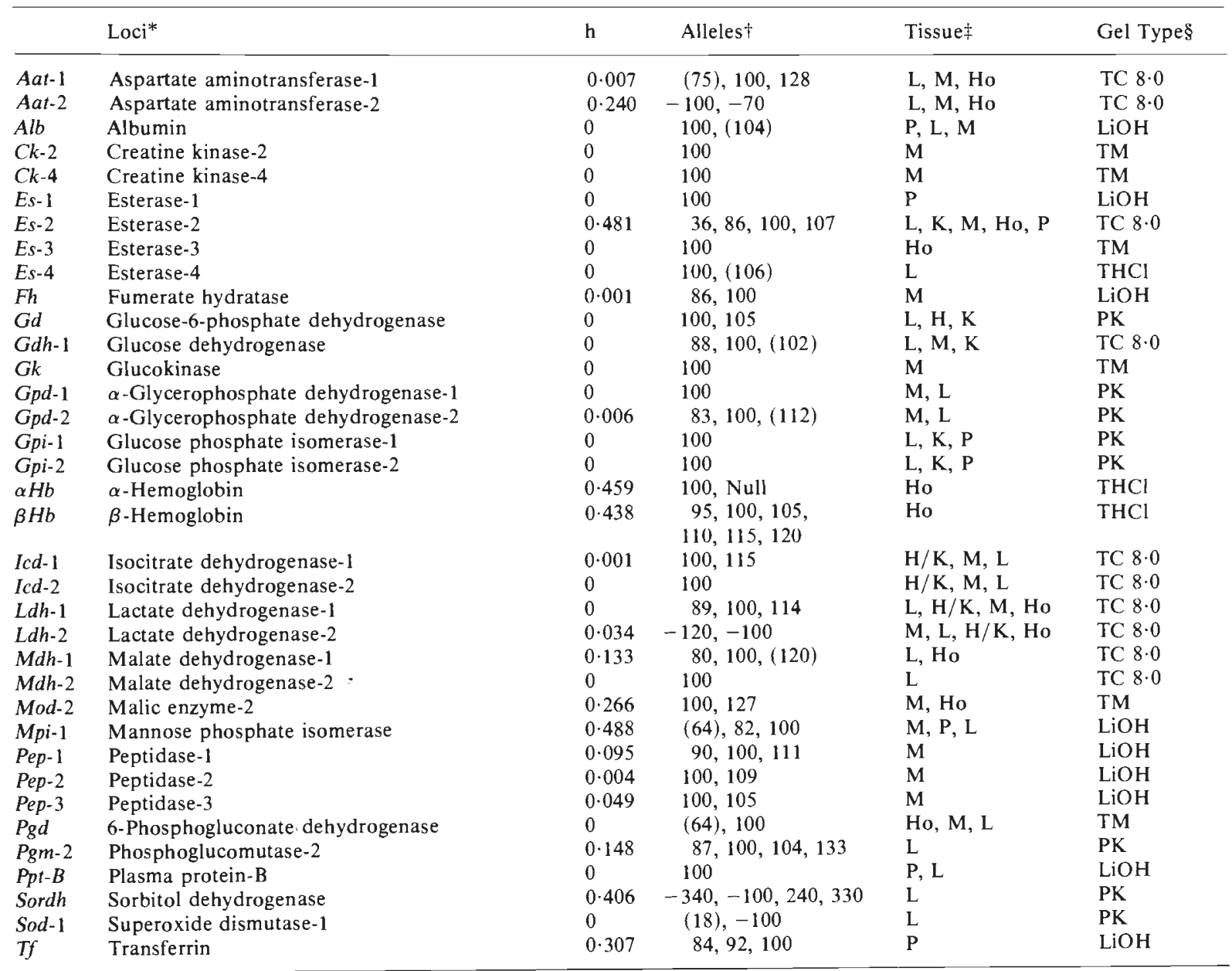

* The following loci have been referred to by other abbreviations: Aat as Got, Es as Est, Gk as Hk, Gpi as Pgi or Phi, Icd as Idh, Mdh as Mor, Mod as Me, Mpi as Pmi, Pgd as 6-Pgd, Sordh as Sdh, Sod as Ipo or To, and Tf as Trf.

+ Alleles in parentheses were not found on the SRP but from locations as follows: Aat- ${ }^{75}$, Alb $^{104}, G^{1} d-2^{112}, M d h-1^{120}, M^{i-1^{64}}$, $P g d-1^{64}$, and $S o d-1^{18}$ from Michigan (Manlove, 1979). Es-4 ${ }^{106}$ and $P g d-1^{64}$ from Texas (Erickson, 1979); Gdh-1 ${ }^{102}$ from Suriname (Smith et al., 1986).

$\ddagger$ Tissue types are listed from most preferred on the left to the least preferred on the right with $\mathrm{Ho}=\mathrm{hemolysate}, \mathrm{H}=\mathrm{heart}$, $\mathrm{H} / \mathrm{K}=$ heart and kidney combination, $\mathrm{L}=$ liver, $\mathrm{M}=$ muscle, and $\mathrm{P}=$ plasma.

$\S \mathrm{Gel}$ types are as follows: $\mathrm{LiOH}=$ Lithium hydroxide, $\mathrm{PK}=$ Poulik (discontinuous tris-citrate), $\mathrm{TC} 8 \cdot 0=$ continuous tris-citrate, $\mathrm{THCl}=$ Tris-hydrochloric acid, $\mathrm{TM}=$ Tris-maleate (Manlove et al., 1975).

categories of $0,>0-0 \cdot 2,>0 \cdot 2-0 \cdot 4$, and $>0 \cdot 4$ for both data sets. The data for $A$ and $h$ for mammals in general (Smith et al., 1978) were grouped into the same categories and comparisons with the data from white-tailed deer were made using Chi-square goodness of fit and contingency tests (Sokal and Rohlf, 1969). The expected values for goodness of fit tests were calculated by multiplying the proportion of observations in each category for mammals times the total number of loci analysed for deer.
Yates' correction was used when expected values were less than five.

The $h$ and $A$ values also were grouped into categories based on the quaternary structure of the assayed proteins (monomers, dimers, and tetramers; Ward, 1977) and on their functional characteristics (group I = single substrate enzymes; group $\mathrm{II}=$ multi-substrate enzymes; group $\mathrm{III}=$ nonenzymatic proteins; Gillespie and Kojima, 1968). Mean $H$ and $A$ values were calculated for 
SRP and overall white-tailed deer, and one-way analyses of variance were calculated using an arcsin-square-root transformation of $h$ values and a square-root transformation of $A$ values. Statistical significance was accepted when the alpha level of probability $(p)$ was $\leq 0 \cdot 05$.

\section{RESULTS}

Twenty-three of the 36 loci studied were not polymorphic at $p \geq 0.01$ for SRP deer (table 1). Of these monomorphic loci, Aat-1, Gpd-2, Icd-1, Ldh1 and $P e p-2$ each had at least one rare allele. Aat-2, Es-2, $\alpha H b, \beta H b, L d h-2, M d h-1, M o d-2, M p i-1$, Pep-1, Pep-3, Pgm-2, Sordh and Tf were polymorphic at $p \geq 0 \cdot 01$ and all of these except $L d h-2$ and $P e p-3$ were also polymorphic at $p=0 \cdot 02$. Additional alleles were observed for some of the 36 loci in deer from areas outside the SRP (table 1). Single locus heterozygosity, known alleles, and preferred tissues and gel types for 36 loci (table 1) were studied using only some of the possible tissue-gel combinations.

Percentages of loci polymorphic at the 0.01 and 0.05 levels were $P_{0.01}=36.0$ per cent and $P_{0.05}=$ 30.6 per cent for the SRP deer, and $P_{0.01}=41.5$ per cent and $P_{0.05}=32.3$ per cent for white-tailed deer overall. The $P_{0.01}$ for white-tailed deer lies near the upper end of the expected distribution for mammals $\left(P_{0.01}=19 \cdot 1 \pm 27 \cdot 4\right.$ per cent $(2 \mathrm{SD})$; Nevo et al., 1984) and is well into the higher half of the expected distribution for vertebrates $\left(P_{0 \cdot 01}=\right.$ $22 \cdot 6 \pm 29 \cdot 2$ per cent $(2 \mathrm{SD}))$.

$\bar{H}$ for the 36 loci examined in SRP deer was $9.9 \pm 2.8$ per cent. This value is lower than the mean reported by Ramsey et al. (1979) for SRP white-tailed deer $(\tilde{H}=12 \cdot 7 \pm 6 \cdot 7$ per cent $)$ but well within the expected distribution of their estimate. The combined estimate of $\bar{H}$ for the 66 loci studied in white-tailed deer in Maryland and at the SRP was $10 \cdot 4 \pm 2 \cdot 4$ per cent. This value is in the higher end of the expected distribution for mammals $(\bar{H}=4 \cdot 1 \pm 3 \cdot 5$ per cent; Nevo et al., 1984) and in the upper half of the expected distribution for vertebrates $(\bar{H}=5.4 \pm 5.9$ per cent; Nevo et al., 1984). The frequency distributions of loci for various levels of heterozygosity in white-tailed deer overall, in SRP white-tailed deer and for mammals in general are given in fig. 1. Contingency $\mathrm{Chi}$ square analyses of frequency of occurrence within heterozygosity classes (based on the number of loci per class) indicated significant differences

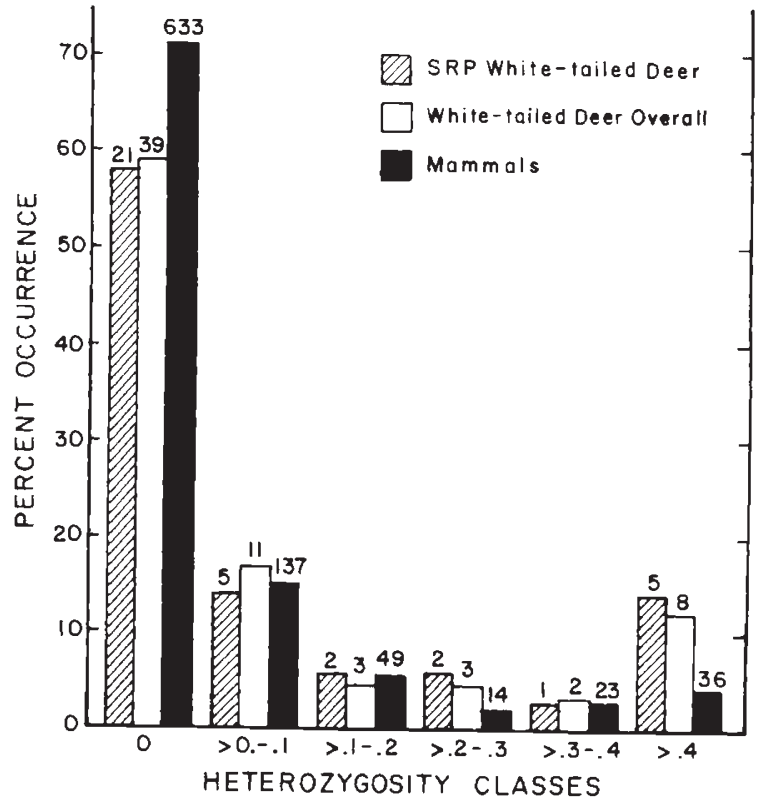

Figure 1 Per cent occurrence of loci of various levels of heterozygosity $(h)$ for white-tailed deer overall or from the Savannah River Plant (SRP) only and for mammals in general (Smith et al., 1978). The latter category does include white-tailed deer as one of many species examined. Numbers of species-locus combinations in each class are given above each bar.

between white-tailed deer overall and mammals in general $(p=0 \cdot 02)$. Frequency distributions for heterozygosity classes were not significantly different between SRP deer and mammals in general $(p=0 \cdot 06)$. Neither the SRP white-tailed deer nor the white-tailed deer overall fit the expected frequency distribution for loci within heterozygosity classes for mammals in general $(p=0.05$ and $0 \cdot 02$, respectively). Deer had fewer homozygous loci and more highly heterozygous loci than did mammals in general.

$A$ for SRP deer and white-tailed deer overall was $1.89( \pm 0.41(2 \mathrm{SE}))$ and $1.94( \pm 0.27)$, respectively. The frequency distribution of $\boldsymbol{A}$ differed significantly between the SRP herd and that of mammals in general, and between the latter and that of white-tailed deer overall, when tested by the contingency or goodness of fit tests $(p=0.01$ to $0 \cdot 001$; fig. 2 ). Deer have more alleles per locus on the average than do other mammals $(A=1 \cdot 24$; calculated from data in fig. 2).

There were no significant differences among $\bar{H}$ or $A$ of white-tailed deer overall based upon protein quaternary structure (monomers, dimers, and tetramers; table 2). Single substrate enzymes, multisubstrate enzymes, and nonenzymatic pro- 




Figure 2 Per cent occurrence of number of alleles per locus for white-tailed deer overall or from the Savannah River Plant (SRP) and for mammals in general (Smith et al., 1978). The overall white-tailed deer values include data from five areas on two continents. The latter category does include white-tailed deer as one of many species examined. Numbers of species-locus combinations in each class are given above each bar.

teins also did not differ significantly in $\bar{H}$ or $A$. $A$ values showed a slight increase from single substrate enzymes to multisubstrate enzymes, and from multisubstrate enzymes to nonenzymatic proteins; $\bar{H}$ did not show this trend.

\section{DISCUSSION}

Data for allele frequencies at eight loci are reported for the first time for SRP deer. These include $C k-2$, Ck-4, Fh-1, Gk, Mpi-1, Pep-1, Pep-2, and Pep-3.
Sheffield (1983) studied all of these loci except Pep in Maryland white-tailed deer, and Smith et al. (1986) studied Pep-1 and $C k-2$ in Suriname deer. Three of these loci ( $M p i-1$, and Pep-1 and 3) were variable at the 0.01 level in SRP white-tailed deer. The number of alleles per locus for white-tailed deer overall approaches 2 . This number is high relative to that for mammals in general, but most species have not been sampled as intensively as SRP white-tailed deer, where minimal sample size for a locus is 500 deer. If sample sizes were increased for other herds, $A$ would be expected to continue to increase gradually. Most secondary alleles occur in low frequency, and only one case of alternate fixation of alleles in different whitetailed deer populations is known ( $G d h-1$; Smith et al., 1986).

The accuracy of estimates of multilocus heterozygosity depends on sample size and number of loci analysed (Nei, 1975; Nevo, 1978). The latter is most important and comparisons of $\bar{H}$ s based on low numbers of loci are influenced heavily by the specific loci included in the sample. Most other reports of $\bar{H}$ in white-tailed deer have been based on 17 to 22 loci (Erickson, 1979; Manlove, 1979; Price et al., 1979; Ramsey et al., 1979; Baccus et al., 1983; Hillestad, 1984; Smith et al., 1984; Smith et al., 1986). Estimates of $\bar{H}$ in these studies varied considerably $(2 \cdot 3-13 \cdot 2$ per cent $)$. At least a small part of this variation is due to the different loci included in the studies. For example, Ramsey et al. (1979) found $\vec{H}=12.7$ per cent for 22 loci, Baccus et al. (1983) found $\bar{H}=7.4$ per cent for 19 loci, and Hillestad (1984) found $\bar{H}=11 \cdot 3$ per cent for 18 loci; all three studies were for deer from the SRP but not for the same years or specific locations.

The largest changes in $\bar{H}$ are related to locational differences. The lowest values were found by Price et al. $(1979 ; \bar{H}=2 \cdot 3$ per cent $)$ for a fenced

Table 2 Summary of genetic variability in proteins of white-tailed deer overall and from the Savannah River Plant (SRP). Genetic variability denoted as alleles per locus $(A)$, mean multilocus heterozygosity $(\vec{H})$, and proportion of polymorphic loci at the 0.05 level $(P)$ relative to quaternary structure and functional groups. Number of loci is given as $N$.

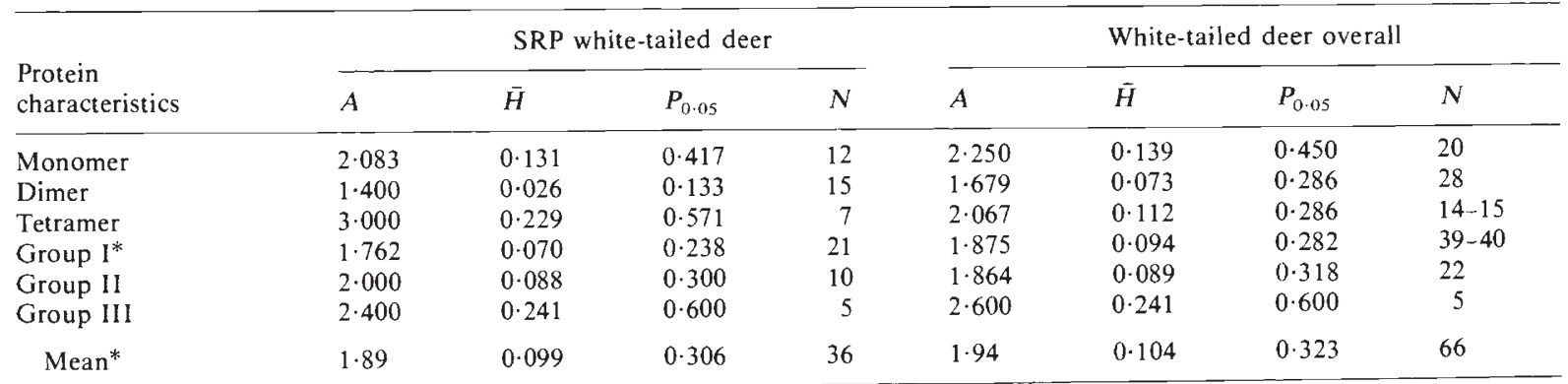

* I= single substrate enzymes, $I I=$ multisubstrate enzymes, and $I I I=$ nonenzymatic proteins. 
population in Arkansas, by Smith et al. (1986; $\bar{H}=3.6$ per cent) for a Suriname population, and by Hillestad ( $1984 ; \bar{H}=4 \cdot 5$ per cent) for an island population in Georgia. In addition, Hillestad found a 23 per cent reduction in $\bar{H}$ for stocked populations vs that of native populations. Ramsey et al. (1979) found significant differences in $\bar{H}$ between populations located a few kilometres apart in the swamp and upland areas on the SRP. Our estimates of $\vec{H}$ for SRP white-tailed deer $(\bar{H}=$ 9.9 per cent $)$ and for whitetails overall $(\bar{H}=10 \cdot 4$ per cent) are within the distribution of $\bar{H}$ for native populations in the southeast studied by Hillestad ( $\vec{H}=5 \cdot 3$ to $11 \cdot 3$ per cent). Low $\bar{H}$ s in particular areas could be historical in nature and reflect drift due to low population numbers.

Estimates of $P$ also indicate that genetic variability is related to location. Populations with low $\bar{H}$ values had low $P$ values $\left(P_{0.01}=11.8\right.$ per cent: Price et al., 1979; $P_{0.01}=10.5$ per cent: Smith et al., 1986; $P_{0 \cdot 01}=22 \cdot 2$ per cent: Hillestad, 1984). $P$ for white-tailed deer overall $\left(P_{0.01}=41.5\right.$ per cent $)$ and for the SRP herd $\left(P_{0.01}=36.0\right.$ per cent $)$ was similar to several previously reported values $\left(P_{0.01}=35.8\right.$ per cent: Baccus et al., $1983 ; P_{0.01}=$ 22.2 per cent to 50.0 per cent: Hillestad, 1984; $P_{0.01}=36.8$ per cent: Smith et al., 1986). Species with widespread distributions should have large variances in $P$ and $\bar{H}$ (Nevo, 1978), and while our data support this contention, all three measures of genetic variability $(\bar{H}, P$, and $A)$ for deer in the southeastern United States are high. Island and penned deer both have low genetic variability (Price et al., 1979; Hillestad, 1984), and this observation is consistent with the hypothesis that the reduction in heterozygosity is caused by stocking and drift. Whitetails in Texas (Erickson, 1979) and Suriname (Smith et al., 1986), both sampled from native populations, also have low $\bar{H}$ s, which points out the need for further sampling within the range of this widespread species. There is no evidence for population bottlenecks at these locations, although the density in Suriname is quite low (Branan, 1984) and was generally low in Texas for the first half of this century (Sanders, 1941). Thus, low $\bar{H}$ s in some areas are probably due to drift.

White-tailed deer have high $\bar{H}$ values but fall within the expected distribution for both mammals $(\bar{H}=4 \cdot 1 \pm 3.8$ per cent $)$ and vertebrates in general ( $\bar{H}=5 \cdot 4 \pm 5.9$ per cent; Nevo et al., 1984). Whitetailed deer differ from other mammals and vertebrates in general in the way in which their genetic variability is expressed. They do not show a trend for decreasing heterozygosity in proteins with more complex quaternary structures (table 2). Ward (1977) and Livshits and Kobyliansky (1985) reported lower $\bar{h}$ s for tetramers than for dimers, the latter having higher values than those of monomers. Four of the most variable loci in deer are tetramers $(\beta H b, \alpha H b, M o d-2$, and Sordh; table 1). Whitetails also do not show the predicted differences between functional groups of proteins (Gillespie and Kojima, 1968; table 2). Heterozygosity in single substrate enzymes should be lowest followed by that of multi-substrate enzymes and then that of nonenzymatic proteins. High variability was expected in the nonenzymatic proteins, $\alpha H b, \beta H b$ and $T f$ but was not expected for the single substrate enzymes, Mod-2, Mpi-1 and Sordh. The frequency distributions of loci with various numbers of alleles or $h$ values also were significantly different between mammals in general and white-tailed deer (figs 1 and 2). The exact cause of the differences between white-tailed deer and mammals in general is not known, but they may be discovered through studies of the specific properties of the enzymes involved or through a better understanding of the population dynamics of white-tailed deer (Scribner et al., 1985).

White-tailed deer have the highest level of genetic variability among large-grazing mammals ( $\bar{H}=0.0$ per cent in caribou (Rangifer tarandus) and a population of red deer (Cervus elaphus) to $\bar{H}=7 \cdot 0$ per cent in red brocket (Mazama americana); Ryman et al., 1980; Baccus et al., 1983; Dratch, 1983; Gyllensten et al., 1983; Smith et al., 1986). There are 10 species of mammals with $\bar{H}>$ 9.0 per cent (Felis domesticus, Homo sapiens, Microtus agrestis, Myotis californicus, Myotis velifer, Perognathus californicus, Peromyscus maniculatus, Proechimys guarirae, Thomomys bottae, and Odocoileus virginianus), and all have geographical ranges classed as regional or widespread on a continental basis by Nevo et al. (1984) or by us with Hall (1981) as a reference. The category "regional" includes species distributed over hundreds but not thousands of miles. White-tailed deer are included in a small group of mammals with high $\bar{H}$ and widespread distributions. Other aspects of its biology are also useful in predicting that it should be a species with high variability.

Nevo et al. (1984) examined the relationships between heterozygosity and several life history and environmental characteristics. Genetic variability is highest in generalist species with small body size, high longevity, large but patchy distributions, limited mobility, and a solitary or highly social population organisation. White-tailed deer fit the prediction in that they live under a broad environ- 
mental spectrum, and have a long life expectancy and a widespread geographical range. On the other hand, several of its characteristics could lead to a prediction of low genetic variability and these include large body size (Wooten and Smith, 1985), continuous habitat distribution, and a polygamous family structure. Two other characteristics usually associated with high heterozygosity are a large number of individuals in the species and potentially high adult mobility. Multilocus heterozygosity in white-tailed deer must be a function of a number of variables, but the multivariate equation describing the relative importance of these variables is not available.

Despite the comprehensive nature of the analyses of Nevo et al. (1984), the potential importance of intrapopulational selection was not assessed adequately. Selection has been shown to occur at the Sordh or a closely linked locus in whitetails (Baccus et al., 1977). In addition, in white-tailed deer $\bar{H}$ is correlated with antler characteristics (Smith et al., 1982; Scribner et al., 1984), testis size in fawns (Urbston, 1976), body size and fat levels in adult females (Cothran et al., 1983), rates of fetal development (Cothran et al., 1983; Chesser and Smith, in press), and fetal number (Johns et al., 1977; Chesser and Smith, in press). These phenotypic correlates of heterozygosity do not prove selection for high $\bar{H}$, but indirectly suggest the importance of the association of heterozygosity levels and fitness in white-tailed deer as seems to be the case for a variety of organisms (Mitton and Grant, 1984). Factors responsible for this type of selection need to be identified and studied before a complete understanding of the role of high heterozygosity in southeastern whitetails is possible. However, the phenetic correlates of heterozygosity suggest it may be a useful characteristic for the management of deer populations (Smith et al., 1976).

Acknowledgements This work was supported by Contract DEAC09-76SR00819 between the U.S. Department of Energy and the University of Georgia's Institute of Ecology. The senior author was supported by a summer fellowship from DOE. We thank Paula Johns, Patrick McKinney and Vernon Osteen for assistance in the laboratory, Joan Lowery and June Peyton for secretarial support and Jerry Choate, Walter Conley, James Novak, Steve Sheffield, Peter Stangel, Deanna Tolliver, and Robert Warren for criticising an early version of the paper.

\section{REFERENCES}

BACCUS, R., HillestAD, H. O., JOHNS, P. E., MANLOVE, M. N., MARChinton, R. L. AND SMITH. M. H. 1977. Prenatal selection in white-tailed deer. Proc. Ann. Conf. Southeast Assoc. Fish \& Wildl. Agencies, 31, 173-179.
BACCUS, R., RYMAN, N., SMITH, M. H., REUTERWALL, C. AND CAMERON, D. 1983. Genetic variability and differentiation of large grazing mammals. J. Mammal., 64, 109-120.

BRANAN, W. V. 1984. Ecology and Management of Deer in Suriname, South America. Unpublished Ph.D. Dissertation University of Georgia, Athens. 154 pp.

CHESSER, R. K., SMITH, M. H., JOHNS, P. E., MANLOVE, M. N., STRANEY, D. O. AND BACCUS, R. 1982 Spatial, temporal and age-dependent heterozygosity of beta-hemoglobin in white-tailed deer. J. Wildl. Mgmt., 46, 983-990.

CHESSER, R. K. AND SMITH, M. H. Relationship of genetic variation to growth and reproduction in the white-tailed deer. Proc. Biology of the Cervidae Symp., Front Royal, Va. In press.

COTHRAN, E. G., CHESSER, R. K., SMITH, M. H. AND JOHNS, P. E. 1983. Influences of genetic variability and maternal factors on fetal growth in white-tailed deer. Evolution, 37, 282-291.

CROW, J. F. AND KimURA, M. 1970. An Introduction to Population Genetics Theory. Harper and Row, New York.

DIMICHELE, L. AND POWERS, D. A. 1982. Physiological basis for swimming endurance differences between $L d h-B$ genotypes of Fundulus heteroclitus. Science, 216, 10141016.

DRATCH, P. A. 1983. Genetic Subdivision in Scottish Red Deer and North American Wapiti. Ph.D. Dissertation, University of Edinburgh, Edinburgh, 150pp.

ERICKSON, M. 1979. Genetics of White-Tailed Deer of South Texas. M.Sc. Thesis, Texas Tech University, Lubbock, $45 \mathrm{pp}$.

GILlespie, J. H. AND KOJIMA, K. 1968. The degree of polymorphisms in enzymes involved in energy production compared to that in non-specific enzymes in two Drosphila ananassae populations. Proc. Natl. Acad. Sci., 61, 582585.

GYLLENSTEN, U., RYMAN, N., REUTERWALl, C. AND DRATCH, P. 1983. Genetic differentiation in four European subspecies of red deer (Cervus elaphus L.). Heredity, 51, 561-580.

HALl, E. R. 1981. The Mammals of North America, 2nd Edition. Vols. I and II. John Wiley \& Sons, $1181 \mathrm{pp}$.

HARRIS, H. AND HOPKINSON, D. A. 1976. Handbook of Enzyme Electrophoresis in Human Genetics. North Holland Publ. Co., Amsterdam.

HARTL, D. L. 1980. Principles of Population Genetics. Sinauer Associates, Sunderland, Massachusetts, 488pp.

HILlESTAD, H. O. 1984. Stocking and Genetic Variability of White-Tailed Deer in the Southeastern United States. Ph.D. Dissertation, University of Georgia, Athens, 112 pp.

HUISMAN, T. H. J., DOZY, A. M., BLUNT, M. H. AND HAYES, F. A. 1968. The hemoglobin heterogeneity of the Virginia white-tailed deer: a possible genetic explanation. Arch. Biochem. Biophys., 127, 711-717.

JOHNS, P. E., BACCUS, R., MANLOVE, M. N., PINDER, J. E., III AND SMITH, M. H. 1977. Reproductive patterns, productivity and genetic variability in adjacent white-tailed deer populations. Proc. Ann. Conf. Southeast Assoc. Game and Fish Comm., 31, 167-172.

LIVSHITS, G. AND KOBYLIANSKY, E. 1985. Lerner's concept of developmental homeostasis and the problem of heterozygosity level in natural populations. Heredity, 55, 341-353.

MANlove, M. H. 1979. Genetic Similarity Among Contiguous and Isolated Populations of White-Tailed Deer in Michigan. M.S. Thesis. Michigan State University, East Lansing, 26pp. 
MANLOVE, M. N., AVISE, J. C., HILlestad, H. O., RAMSEY, P. R., SMITH, M. H. AND STRANEY, D. O. 1975. Starch gel electrophoresis for the study of population genetics in white-tailed deer. Proc. Ann. Conf. Southeast. Assoc. Game Fish Comm., 29, 392-403.

MANLOVE, M. N., SMITH, M. H., HILLESTAD, H. O., FULLER, S. E., JOHNS, P. E. AND STRANEY, D. O. 1976. Genetic subdivision in a herd of white-tailed deer as demonstrated by spatial shifts in gene frequencies. Proc. Ann. Conf. Southeast. Assoc. Game and Fish Comm., 30, 487-492.

MITTON, J. B. AND GRANT, M. C. 1984. Associations among protein heterozygosity, growth rate and developmental homeostasis. Ann. Rev. Ecol. and Syst., 15, 479-499.

NEI, M. 1975. Molecular Population Genetics and Evolution. North Holland Publ. Co., Amsterdam, 278pp.

NEVO, E. 1978. Genetic variation in natural populations: patterns and theory. Theor. Pop. Biol., 13, 121-177.

NEVO, E., BEILES, A. AND HEN-SHLONO, R. 1984. The evolutionary significance of genetic diversity: ecological, demographic and life history correlates. In Mani, G. S. Evolutionary Dynamics of Genetic Diversity, pp. 132-213. Proceedings, Manchester 1983, Springer-Verlag.

NICHOLS, E. A., CHAPMAN, V. M. AND RUDDLE, F. H. 1973. Polymorphism and linkage for mannosephosphate isomerase in Mus musculus. Biochem. Genet., 8, 47-53.

PRICE, P. K. CARTWRIGHT, M. AND ROGERS, M. J. 1979. Genic variation in white-tailed deer from Arkansas. Proc. Ark. Acad. Sci., 23, 64-66.

RAMSEY, P. R., AVISE, J. C., SMITH, M. H. AND URBSTON, D. F. 1979. Biochemical variation and genetic heterogeneity in South Carolina deer populations. J. Wildl. Mgmt., 43, 136142.

RYMAN, N., REUTERWALL, C., NYGREN, K. AND NYGREN, T. 1980. Genetic variation and differentiation in Sandinavian moose (Alces alces): Are large mammals monomorphic? Evolution, 34, 1037-1049.

SANDERS, E. 1941. A preliminary report on the study of whitetailed deer in the Edwards Plateau of Texas. J. Wildl. Mgmt., 5, 182-190.

SCRIBNER, K. T., SMITH, M. H. AND JOHNS, P. E. 1984. Age, condition, and genetic effects on incidence of spike bucks. Proc. Ann. Conf. Southeast Assoc. Fish and Wildl. Agencies, 38, 23-32.

SCRIBNER, K. T., WOOTEN, M. C., SMITH, M. H. AND JOHNS, P. E. 1985. Demographic and genetic characteristics of white-tailed deer populations subjected to still or dog hunt- ing. In Beasom, S. L. and Roberson, S. F. (eds.) Proc. Symposium on Game Harvest Management, Caesar Kleberg Wildl. Research Inst., Kingsville, TX, pp. 197-212.

SELANDER, R. K., SMITH, M. H., YANG, S. Y., JOHNSON, W. E. AND GENTRY, J. B. 1971. IV. Biochemical polymorphism and systematics in the genus Peromyscus. I. Variation in the old-field mouse (Peromyscus polionotus). Studies in Genetics VI, 50-90, Univ. Texas Publ. 7103.

SHEFFIELD, S. R. 1983. Genetic Variation and Differentiation in White-Tailed Deer (Odocoileus virginianus) Populations in Maryland. M.S. Thesis. Frostburg State Coll., Frostburg, 92pp.

SMITH, M. H., BRANAN, W. V., MARCHINTON, R. L., JOHNS, P. E. AND WOOTEN, M. C. 1986. Genetic and morphological comparisons of red brocket, brown brocket and whitetailed deer. J. Mammal., 67, 103-111.

SMITH, M. H., HILlESTAD, H. O., BACCUS, R. AND MANLOVE, M. N. 1984. Population genetics of the white-tailed deer. In Halls, L. (ed.) Ecology and Management of White-Tailed Deer, Stackpole books, New York, pp. 119-128.

SMITH, M. H., CHESSER, R. K., COTHRAN, E. G. AND JOHNS, P. E. 1982. Genetic variability and antler growth in a natural population of white-tailed deer. In Brown, R. D. (ed.) Antler Development in Cervidae, Caesar Kleberg Wildl. Research Institute, Kingsville, Texas, pp. 365-387.

SMITH, M. H., HILLESTAD, H. O., MANLOVE, M. N. AND MARCHINTON, R. L. 1976. Use of population genetics data for the management of fish and wildlife populations. Trans. N. Amer. Wildl. Nat. Res. Conf., 41, 119-123.

SMITH, M. H.. MANLOVE, M. N. AND JOULE, J. 1978. Spatial and temporal dynamics of the genetic organization of small mammal populations. In Snyder, D. P. (ed.). Populations of Small Mammals Under Natural Conditions, Vol. 5, Univ. of Pittsburgh Press, pp. 99-113.

SOKAL, R. R. AND ROHLF, F. J. 1969. Biometry. W. H. Freeman and Co. San Francisco, 776pp.

TAMARIN, R. H. AND KREBS, C. J. 1973. Selection at the transferrin locus in cropped vole populations. Heredity, 30, 53-62.

URbSTON, D. F. 1976. Descriptive Aspects of Two Fawn Populations as Delineated by Reproductive Differences. Unpublished Ph.D. Dissertation, Virginia Polytechnic Institute, Blacksburg, 104pp.

WARD, R. D. 1977. Relationship between enzyme heterozygosity and quaternary structure. Biochem. Gen., 15, 123-135.

WOOTEN, M. C. AND SMITH, M. H. 1985. Large mammals are genetically less variable? Evolution, 39, 210-212. 